\title{
Effects of Storage and Heating on Serum Viscosity of Commercial Hot Break Tomato Paste
}

\author{
Hye Won Yeom, Marco Ramirez and Joseph Conte \\ Campbell Soup Company, Campbell Place, Camden, New Jersey 08103, USA
}

\begin{abstract}
Samples of hot break tomato paste were collected from commercially produced aseptic totes after 6-11 months of storage at ambient temperature. Serum viscosity of the hot break tomato paste samples was analyzed at each sampling time and compared to the initial serum viscosity measured at the time of tomato paste manufacturing. As storage time increased, the serum viscosity of hot break tomato paste significantly decreased. After 7 months of storage, 16\%-27\% reduction of serum viscosity was observed in the hot break tomato paste. To evaluate effects of a heating on the serum viscosity of hot break tomato paste, the paste samples were reconstituted with water to $10^{\circ}$ Brix, similar level of tomato solids in typical tomato sauce products. Diluted tomato paste was heated and held at $95{ }^{\circ} \mathrm{C}$ for 3 minutes and its serum viscosity was measured. After the heating, the serum viscosity of hot break tomato paste was slightly increased up to $5 \%$ of initial value, however the recovery was not significant $(p<0.05)$.
\end{abstract}

Key words: Hot break tomato paste, serum viscosity, storage, heating of reconstituted hot break paste.

\section{Introduction}

In United States, majority of tomatoes are thermally processed and concentrated into tomato paste [1]. Tomato variety and its maturity significantly affected the texture of processing tomatoes [2]. Harvesting and handling condition of fresh tomatoes also affected texture quality of tomato juice [3]. Tomato processing variables such as finisher screen size and breaking temperature influenced consistency of tomato paste [4]. Tomato paste can be produced by the cold break process or the hot break process [5]. Hot break tomato paste process involves a rapid heating of chopped tomatoes to $>90{ }^{\circ} \mathrm{C}$ and cold break tomato pastes is processed at $60-77{ }^{\circ} \mathrm{C}$ [6]. The hot break process inactivates pectin hydrolyzing enzymes [7]. Therefore, hot break tomato juice has significantly higher viscosity than cold break tomato juice [8]. Hot break tomato paste is used in a tomato sauce which is the most popular canned vegetable product in U.S. [9]. Pectin in tomato paste influences the textural properties of tomato products because of its

Corresponding author: Hye Won Yeom, Ph.D., research fields: vegetable and functional ingredients. thickening and gel-forming capabilities [1, 10]. Chemical properties of pectin in the hot break tomato paste were different from pectin in the cold break tomato paste [11]. Serum viscosities are determined by the properties of the soluble polymers (primarily pectin) in the tomato juice, while the Bostwick consistencies are affected mostly by the insoluble material [12].

Concentrated tomato paste is packed in bulk containers such as drums or totes, and stored for use for up to 18 months [13]. After storage, a hot break tomato paste is diluted with water, mixed with other ingredients, pumped, cooked, and bottled for production of sauces [14]. High viscosity of hot break tomato paste is important to quality of tomato sauce [15]. Consistency loss of tomato paste has been reported during tomato paste manufacturing [1]. Tomato processing methods significantly contributed to viscosity of hot break tomato juice [16]. Effects of industrial tomato processing and storage on nutrients of hot break tomato paste have been reported [17]. Consistency loss of tomato paste during storage was observed in small bags manufactured with a preservative on a laboratory scale [12]. However, 
viscosity of commercially produced and stored hot break tomato paste has not been analyzed during storage.

The objective of this study was to monitor serum viscosity of hot break tomato paste produced and stored on commercial scale during storage time. Serum viscosity of hot break tomato paste was also measured after storage, dilution, and heating to verify whether the serum viscosity of hot break tomato paste could be recovered during a manufacturing of tomato sauce products.

\section{Materials and Methods}

2.1 Manufacturing and Storage of Hot Break Tomato Paste

Aseptic hot break tomato paste (total solids 34\%) was commercially manufactured at multiple tomato paste plants in California. The aseptic hot break tomato paste was packed into $1,360 \mathrm{~kg}$ of totes and stored at ambient temperature in California (Fig. 1). Later, the aseptic totes were moved to commercial food manufacturing plants in Ohio and Texas for manufacturing of tomato sauce products.

\subsection{Sampling of Hot Break Tomato Paste}

Hot break tomato paste sample was collected at the commercial food manufacturing plants in Ohio and Texas when the aseptic tote was open and hot break tomato paste was pumped into a blending tank (Fig. 2). At each sampling time, total 10 samples were collected from 10 different totes. Size of each sample was $2 \mathrm{~kg}$ and the hot break tomato paste samples were frozen and shipped to tomato plant's analysis laboratory for further analysis. To make sure that a freezing of hot break paste does not affect its serum viscosity, the serum viscosity of hot break paste was measured before and after a freezing process, and there was no difference observed.

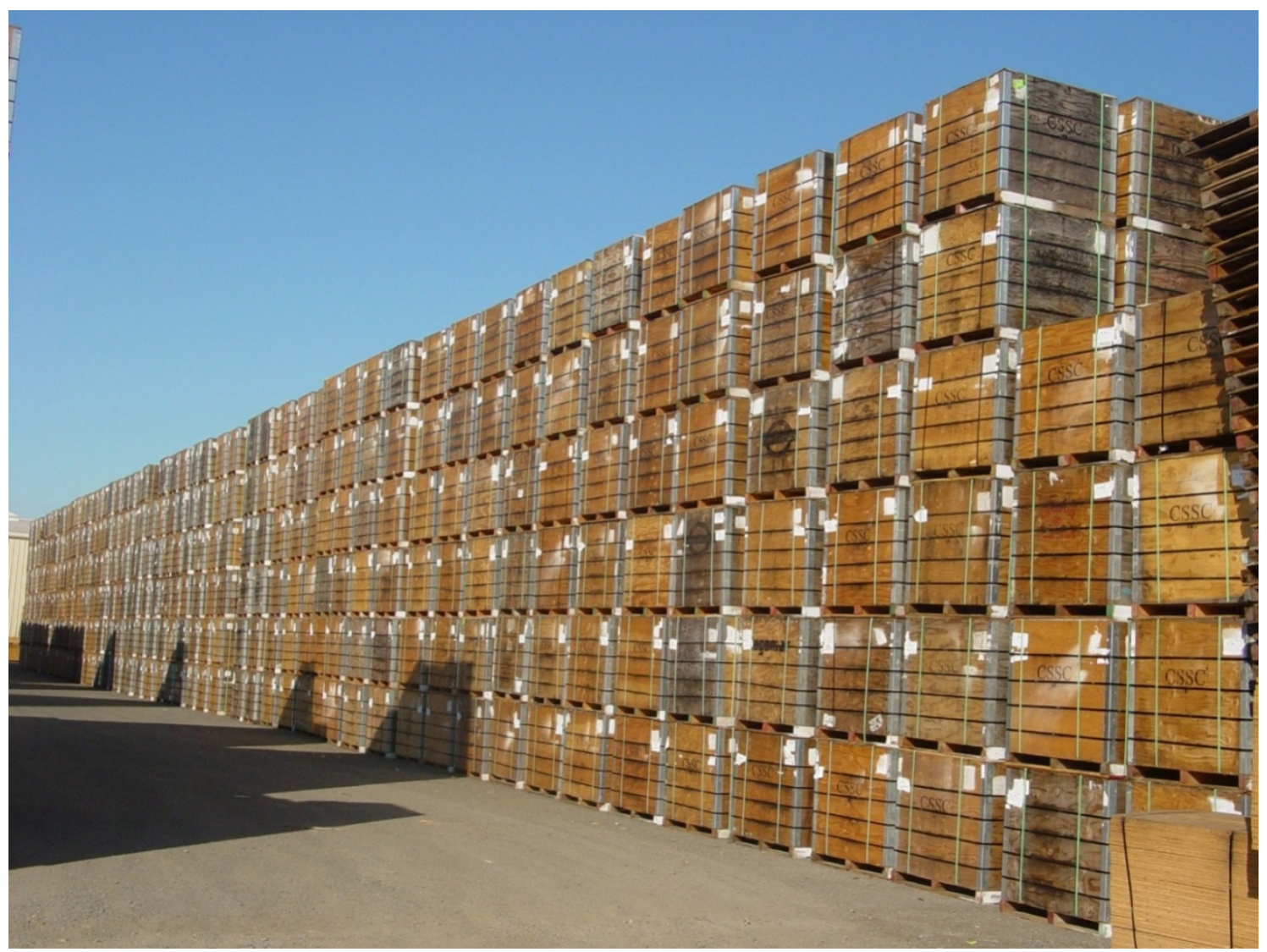

Fig. 1 Storage of commercial aseptic hot break tomato paste packed in totes. 

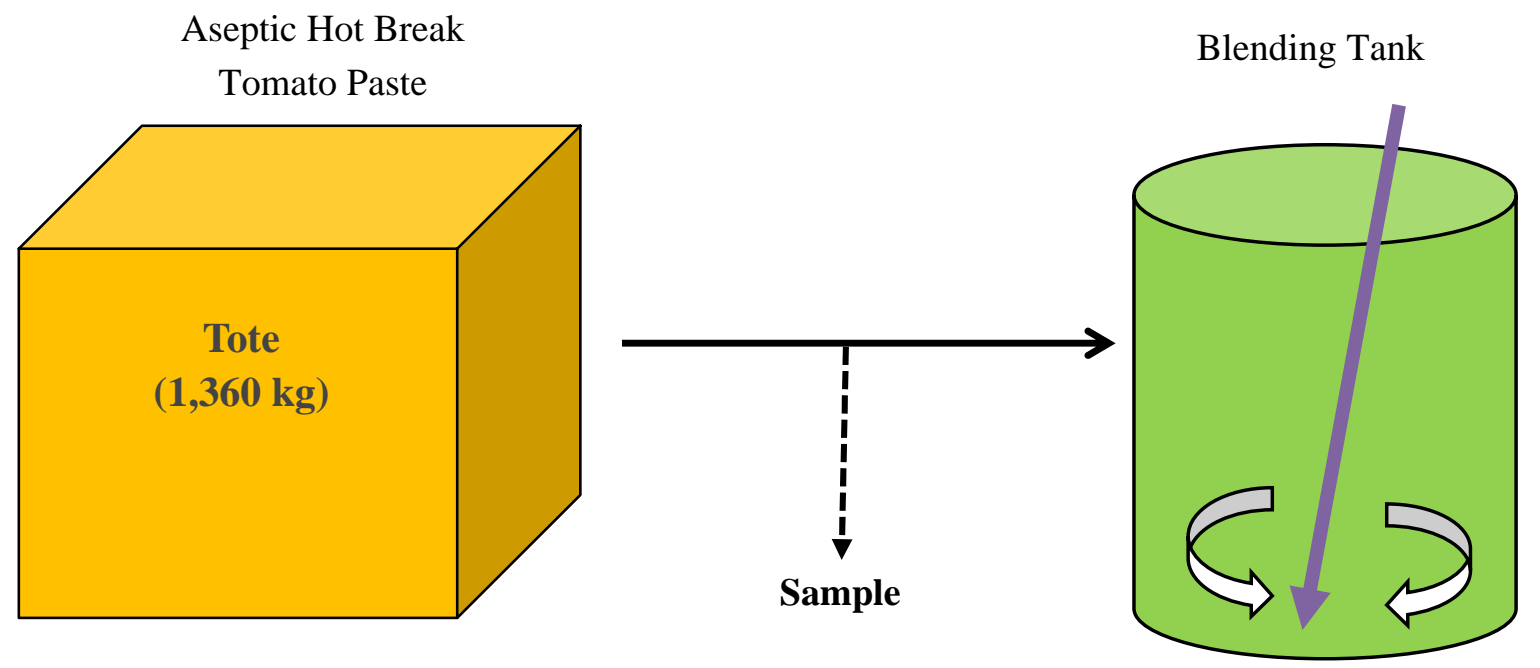

Fig. 2 Sampling of commercial hot break tomato paste after storage at ambient temperature.

\subsection{Measurement of Serum Viscosity and Calculation} of Relative Serum Viscosity (\%)

Hot break tomato paste was diluted with distilled water to $6.0 \% \pm 0.1 \%$ total solids prior to serum viscosity measurement. Total solids of the diluted hot break tomato paste were analyzed using Microwave Moisture/Solid Analyzer (CEM Lab Wave 9000, CEM Corporation, Matthews, NC). After at least 30 minutes, the diluted hot break paste was filtered through a filter paper (Whatman \#4, Fisher Scientific, Pittsburgh, PA). A $7.0 \mathrm{~mL}$ of the filtrate was filled into the large orifice of the calibrated Ostwald viscometer tube (ASTM size \#100 Ostwald-Cannon-Fenske type Viscometer, Fisher Scientific, Pittsburgh, PA) and the tube was placed in the water bath controlled at $25 \pm 1{ }^{\circ} \mathrm{C}$. After 10 mins of temperature equilibration, suction was applied to draw the liquid a short distance above the upper graduated mark. With both orifices open to the air, time was recorded in seconds for the liquid to pass between the graduation above and below the lower bulb. Serum viscosity (seconds) was calculated as follows:

Calibration factor $=60$ seconds/Avg. time for deionized water runs

Serum viscosity $(\mathrm{sec})=$ Sample time $\times$ Calibration Factor
Initial serum viscosity of the hot break tomato paste samples collected from different lots and totes could be different, therefore a relative serum viscosity (\%) was used for comparison.

Relative serum viscosity $(\%)=$ Serum viscosity after storage (and heating) $\times 100(\%) /$ Initial serum viscosity measured on each hot paste sample's manufacturing date.

\subsection{Reconstitution and Heating of Hot Break Tomato Paste}

The hot break tomato paste collected after storage was reconstituted with deionized water to $10^{\circ}$ Brix using an electronic 5-speed hand held mixer (Hamilton Beach, Inc., Glen Allen, VA). Brix of diluted hot break tomato paste was measured using a RFM refractometer (Bellingham + Stanley, Royal Tunbridge Wells, UK). Reconstituted hot break paste was heated in a steamed kettle and held at $95{ }^{\circ} \mathrm{C}$ for 3 minutes which was similar to the typical thermal processing conditions for tomato sauce products.

\subsection{Statistical Analysis}

An analysis of the variance (ANOVA) was performed to evaluate the effects of storage and heating on the serum viscosity of hot break tomato paste (Minitab v. 17, 2015, Minitab Inc., State College, PA). The level of significance was set at $p<0.05$. 
Data are the means of 10 samples per each storage time and error bars indicate two standard deviation.

\section{Results and Discussion}

Serum viscosity (\%) of hot break tomato paste was significantly decreased compared to its initial serum viscosity after ambient storage (Fig. 3). A 16\%-27\% reduction of relative serum viscosity was observed in the commercial hot break tomato paste (34\% total solids) after 7 months of storage time at ambient temperature (Fig. 3 and Table 1). Similar degree of serum viscosity reduction, $16 \%-25 \%$, was reported in $28^{\circ}$ Brix hot break tomato paste after storage in sample bags added with a preservative [12]. However, any change of serum viscosity in commercially produced and stored aseptic hot break tomato paste has not been reported before.

Loss of tomato paste's consistency has been reported during manufacturing of tomato pastes at commercial processing plants [18]. Water soluble pectin significantly increased during hot break paste

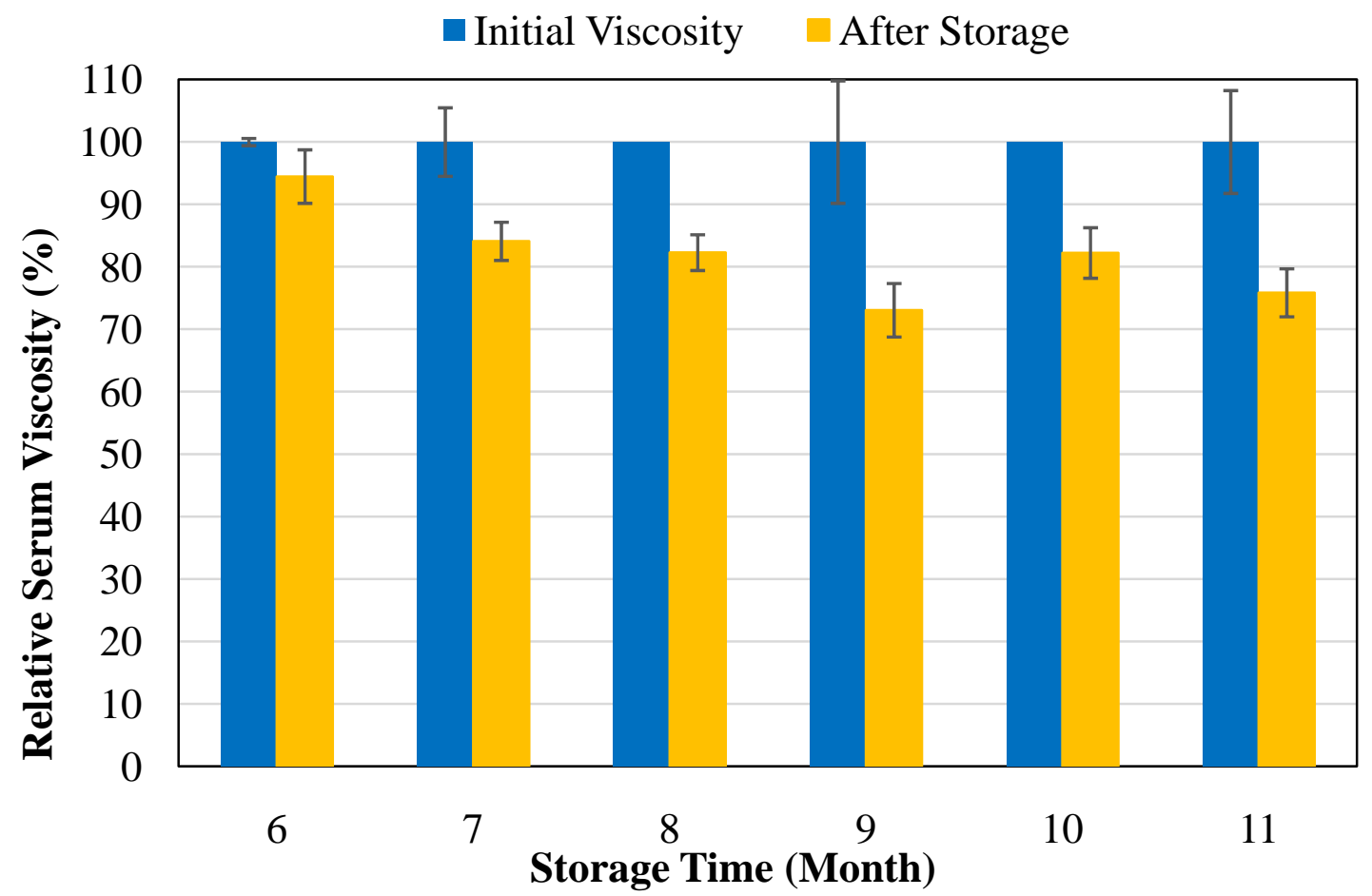

Fig. 3 Relative serum viscosity (\%) of commercial hot break tomato paste after storage at ambient temperature.

Table 1 Relative serum viscosity (\%) of commercial hot break tomato paste after storage and heating. Values shown represent the mean \pm SD $(n=10)$. No significant difference between after storage and after storage/heating $(p<0.05)$.

\begin{tabular}{lll}
\hline $\begin{array}{l}\text { Storage time } \\
\text { (month) }\end{array}$ & Relative serum viscosity after storage (\%) & Relative serum viscosity after storage and heating (\%) \\
\hline 6 & $94.5 \pm 4.3$ & N/A \\
7 & $84.1 \pm 3.1$ & $89.0 \pm 4.0$ \\
8 & $82.3 \pm 2.9$ & $83.1 \pm 4.4$ \\
9 & $73.1 \pm 4.3$ & $76.9 \pm 5.2$ \\
10 & $82.2 \pm 4.0$ & $87.4 \pm 1.5$ \\
11 & $75.9 \pm 3.8$ & $81.5 \pm 5.0$ \\
\hline
\end{tabular}


manufacturing [11]. Tomato concentration conditions affected viscosity of tomato paste manufactured on a pilot scale [19]. Heat input during tomato paste processing had a huge impact on the pectin integrity and viscosity of tomato paste [1]. During the evaporation process, conformational changes in pectin and increase in pectin's solubility were observed in tomato paste with reduction of serum viscosity [20]. Pectin in serum phase is considered to be the most important for rheology of the plant-tissue-based food suspensions [21]. The loss of serum viscosity in commercial hot break tomato paste appears to be caused by heat input during the storage time. Aseptic hot break tomato paste is usually stored at outdoor temperature in California. Average outdoor temperature in Northern California can reach up to $35{ }^{\circ} \mathrm{C}$ during summer [22].

Recovery of the consistency in a hot break tomato paste was reported after storage in sample bags, reconstitution to $5^{\circ}$ Brix and heating at $90{ }^{\circ} \mathrm{C}$ for 30 $\min$ or $100{ }^{\circ} \mathrm{C}$ for $15 \mathrm{~min}$ [12]. In this study, commercial hot break tomato paste was stored in $1,360 \mathrm{~kg}$ aseptic totes, reconstituted to $10^{\circ}$ Brix, heated and hold at $95^{\circ} \mathrm{C}$ for 3 min which was similar to a commercial process of tomato sauce products. After the heating of reconstituted hot break tomato paste $\left(10^{\circ}\right.$ Brix), the relative serum viscosity was slightly recovered up to $6 \%$ of initial serum viscosity (Table 1). However, the recovery was not statistically significant $(p<0.05)$. It indicated that the serum viscosity of commercial hot break tomato paste will not recover its initial value after storage, reconstitution, and heating. Therefore, thickness of tomato sauce products cannot be estimated using the initial serum viscosity of hot break tomato paste which was measured on the day of tomato paste manufacturing. Thickness of tomato sauce products can be varied by the storage time of aseptic hot break tomato paste.

Viscosity is the most important quality parameter for tomato sauce products [9, 23]. Variation in commercial tomato paste's quality causes difficulties in quality control of tomato products [24]. This study verified that serum viscosity of commercially produced and stored hot break tomato paste significantly reduced after storage at ambient temperature. Therefore, storage time of commercial hot break tomato paste should be considered as an important quality parameter for manufacturing of tomato sauce products. However, this study was limited to the storage time of commercial hot break tomato paste at ambient temperature. To monitor effects of storage temperature, it is necessary to conduct a storage study of commercial hot break tomato pastes stored at different temperatures including a refrigeration temperature.

\section{Acknowledgements}

The authors are thankful to Campbell's Agricultural Operation and Campbell's Supply Chain for providing the hot break tomato paste samples and analyzing serum viscosity.

\section{References}

[1] Hurtado, M. C., Greve, L. C., and Labavitch, J. M. 2002. "Changes in Cell Wall Pectins Accompanying Tomato Paste Manufacture.” Journal of Agricultural and Food Chemistry 50: 273-8.

[2] Barrett, D. M., Garcia, E., and Wayne, J. E. 1998. "Texture Modification of Processing Tomatoes." Critical Reviews in Food Science and Nutrition 38 (3): 173-258.

[3] Held, M. T., Anthon, G. E., and Barrett, D. M. 2015. "The Effects of Bruising and Temperature on Enzyme Activity and Textural Qualities of Tomato Juice.” Journal of the Science and Food Agriculture 95: 1598-604.

[4] Sanchez, M. C., Valencia, C., Gallegos, C., Crispulo, G., Ciruelos, A., and Latorre, A. 2002. "Influence of Processing on the Rheological Properties of Tomato Paste.” Journal of the Science and Food Agriculture 82: 990-7.

[5] Kelebek, H., Selli, S., Kadiroglu, P., Kola, O., Kesen, S., Ucar, B., and Cetiner, B. 2017. "Bioactive Compounds and Antioxidant Potential in Tomato Pastes as Affected by Hot and Cold Break Process." Food Chemistry 220: 31-41.

[6] Chong, H. H., Simsek, S., and Reuhs, B. L. 2014. "Chemical Properties of Pectin from Industry Hot and 
Cold Break Tomato Products.” Food and Nutrition Sciences 5: 1162-7.

[7] Moelants, K. R. N., Cardinaels, R., Buggenhout, S. V., Loey, A. M. V., Moldenaers, P., and Hendrickx, M. E. 2014. "A Review on the Relationships between Processing, Food Structure, and Rheological Properties of Plant-Tissue-Based Food Suspensions." Comprehensive Reviews in Food Science and Food Safety 13: 241-60.

[8] Goodman, C. L., Fawcett, S., and Barringer, S. A. 2002. "Flavor, Viscosity, and Color Analyses of Hot and Cold Break Tomato Juices.” Journal of Food Science 67: 404-8.

[9] Apalah, R. K., and Barringer, S. A. 2001. "Quality Loss during Tomato Paste Production versus Sauce Storage." Journal of Food Processing and Preservation 25: 237-50.

[10] Lin, H., Aizawa, K., Inakuma, T., Yamauchi, R., and Kato, K. 2005a. "Physical Properties of Water-Soluble Pectins in Hot- and Cold-Break Tomato Pastes.” Food Chemistry 93: 403-8.

[11] Lin, H., Qin, X., Aizawa, K., Inakuma, T., Yamauchi, R., and Kato, K. 2005b. "Chemical Properties of Water-Soluble Pectins in Hot- and Cold-Break Tomato Pastes." Food Chemistry 93: 409-15.

[12] Anthon, G. E., and Barrett, D. M. 2010. "Changes in Tomato Paste during Storage and the Effects of Heating on Consistency of Reconstituted Tomato Paste.” Journal of Texture Studies 41 (3): 262-78.

[13] USDA Economic Research Service. 2016. "Vegetables \& Pulses: Tomatoes.” Available at: https://www.ers.usda.gov/topics/crops/vegetables-pulses/t omatoes/\#processing.

[14] McCarthy, K. L., and McCarthy, M. J. 2009. "Relationship between in-Line Viscosity and Bostwick Measurement during Ketchup Production.” Journal of Food Science 74 (6): E291-7.

[15] Anthon, G. E., Sekine, Y., Watanabe, N., and Barrett, D. M. 2002. "Thermal Inactivation of Pectin Methylesterase, Polygalacturonase, and Peroxidase in Tomato Juice.”
Journal of Agricultural Food Chemistry 50: 6153-9.

[16] Rge, B., Deepa, N., Jaggi, S., and Kapoor, H. C. 2007. "Viscosity and Quality of Tomato Juice as Affected by Processing Methods.” Journal of Food Quality 30: 864-77.

[17] Asert, S., and Mitchell, A. E. 2012. "Effects of Industrial Tomato Paste Processing on Ascorbic Acid, Flavonoids and Carotenoids and Their Stability over One-Year Storage." Journal of the Science of Food and Agriculture 92: 23-8.

[18] Anthon, G. E., Diaz, J. V., and Barrett, D. M. 2008. "Changes in Pectins and Product Consistency during the Concentration of Tomato Juice to Paste.” Journal of Agricultural Food Chemistry 56: 7100-5.

[19] Diaz, J. V., Anthon, G. E., and Barrett, D. M. 2009. "Conformational Changes in Serum Pectins during Industrial Tomato Paste Production.” Journal of Agricultural Food Chemistry 57: 8453-8.

[20] Moelants, K. R. N., Cardinaels, R., Buggenhout, S. V., Loey, A. M. V., Moldenaers, P., and Hendrickx, M. E. 2014. "A Review on the Relationships between Processing, Food Structure, and Rheological Properties of Plant-Tissue-Based Food Suspensions.” Comprehensive Reviews in Food Science and Food Safety 13: 241-60.

[21] https://weather.com/weather/monthly.

[22] Apalah, R. K., Goodman, C. L., and Barringer, S. A. 2001. "Quality Differences between Fresh Pack and Remanufactured Tomato Sauce.” Journal of Food Processing and Preservation 25: 431-45.

[23] Claybon, K. T., and Barringer, S. A. 2002. "Consumer Acceptability of Viscosity in Processed Tomato Products by African-American, Latino, and Prototypical Consumer Groups.” Journal of Food Science 67 (6): 2380-4.

[24] Bayod, E., Willers, E. P., and Tornberg, E. 2008. "Rheological and Structural Characterization of Tomato Paste and Its Influence on the Quality of Ketchup." LWT-Food Science and Technology 41: 1289-300. 